\title{
LECTURERS' CONSCIOUSNESS LEVEL AND VIEWS ON STRATEGIC PLANNING
}

\author{
OKUTMANLARIN STRATEJIKK PLANLAMA BİLINÇ DÜZEYİ VE STRATEJİK \\ PLANLAMA HAKKINDAKİ GÖRÜŞLERİ
}

\section{Özcan DOĞAN ${ }^{1}$ \\ Yücel ȘiMȘEK ${ }^{2}$}

\begin{abstract}
This study aimed to search the lecturers' (employed at the Eskişehir Osmangazi University, Department of Foreign Languages) consciousness level and views on strategic planning. Although the population includes 70 lecturers at the department, 46 lecturers participated in the study. Because the number of people in this research was limited, convergent parallel mixed methods design was used in the study. In the quantitative part of the study, the data were collected via an instrument called "strategic planning consciousness level instrument," and in the qualitative part of the study, the data were collected by the "strategic planning views form." In the data analysis, KruskallWallis Test, Mann-Whitney U Test and descriptive analysis techniques were used. The results showed that the lecturers' consciousness level of strategic planning and strategic planning belief are low. However, they indicated that strategic planning is important for an organization and it would motivate the employees and enhance the organizational belonging. Moreover, they have middle level negative attitude about strategic planning, and they think that the managers must have the active role in strategic planning.
\end{abstract}

Keywords: strategic planning, lecturers, strategic planning consciousness, university

\section{$\ddot{O} \mathbf{z}$}

Bu çalışmada Eskişehir Osmangazi Üniversitesi Yabancı Diller Bölümü’nde görevli olan okutmanların stratejik planlama bilinç düzeyleri ve stratejik planlama hakkındaki görüşleri araştırılmıştır. Araştırmanın evrenini sözü edilen bölümde görevli olan 70 okutman oluşturmakla birlikte araştırmaya 46 okutman katılmıştır. Araştırma kapsamındaki okutmanların sayısının az olması sebebiyle araştırma karma yöntem araştırma desenlerinden yakınsayan paralel desene göre tasarlanmıştır. Araştırmanın nicel veri toplama bölümünde "stratejik planlama bilinç düzeyi ölçeği”, nitel veri toplama bölümünde ise "stratejik planlama görüş formu” kullanılmıştır. Verilerin analizinde Kruskall-Wallis Testi, Mann-Whitney U Testi ve betimsel analiz teknikleri kullanılmıştır. Araştırma bulgularına göre okutmanların stratejik planlama bilinç düzeylerinin düşük olduğu görülmektedir. Araştırmaya katılan okutmanlar stratejik planlamanın bir örgüt için önemli olduğunu, planlamadan çalışanları haberdar etmenin örgüt çalışanlarını motive edeceğini ve örgüte aidiyet duygusunu arttıracağını belirtmişlerdir. Araştırmaya katılan okutmanların stratejik planlama hakkında orta düzeyde olumsuz tutuma sahip oldukları görülmüştür ve yöneticilerin stratejik planlamada aktif rol almaları gerektiği ifade edilmiştir.

Anahtar Kelimeler: stratejik planlama, okutmanlar, stratejik planlama bilinç düzeyi, üniversite

\footnotetext{
${ }^{1}$ Okutman, Eskişehir Osmangazi Üniversitesi, Yabancı Diller Bölümü, odogan@ogu.edu.tr

${ }^{2}$ Yard. Doç. Dr. Anadolu Üniversitesi, Eğitim Fakültesi, Eğitim Bilimleri Bölümü, Eğitim Yönetimi Anabilim

Dal1 ysimsek@anadolu.edu.tr
} 


\section{INTRODUCTION}

In the world today, there are various factors forcing the individuals and the organisations to change. Under these conditions, it is necessary for the individuals and the organizations to react immediately to adapt to the rapid changes and survive in the competitive environment. In order to react growing needs, the organizations must be able to know themselves and their environment, and they must be planned. Individuals make plans at different scales throughout their lives and set targets for themselves. In addition, people plan their lives so as to reach their aims and decisions. Similarly, the organizations operating in the private and state sector make plans to survive and organize their investments. Planning includes setting the goals, knowing the capacity and determining the methods to be followed in order to reach the goals after examining the environmental factors; therefore, it needs a strategy. According to Floyd (2002), the methods used to reach the goals vary. Strategy means defining the goals of the organization after determining the methods to be used and directing the resources after considering the environmental factors.

In other words, strategy means the methods to be followed while carrying out a work. Before starting the planned work, it is necessary to set the goals, analyse the capacity, choose the methods to follow for the goal and find out the shareholders. Strategy, which helps an organization adapt the rapidly changing environmental factors, is both a process of making decisions and renovation. It includes revealing the goals of an organization and determining the resources and methods to be used for those goals. Besides, strategy means deciding on the vision and mission of an organization (Mintzberg, 2003; cited in Ebner 2012). It is clear that the strategy means moving in a plan and having some methods to reach the goals after comparing the present resources to those of the rivals, and the environmental changes as well.

The strategy, which is a comprehensive plan that states the important steps to follow in order to reach the goals as well as the mission and vision of an organization, decreases the disadvantages and increases the competitive advantages (Hunger and Wheelen, 2011). It is a process of deciding and changing the management of organizations intentionally in accordance with the changing environmental conditions. Therefore, by using a strategy, it is aimed to react quickly to the environmental factors (Olsen, 2007).

Mintzberg (1996) states that strategy is composed of 5Ps which are the initials of Plan, Ploy, Pattern, Position and Perspective. As it is stated, strategy is a plan that is formed intentionally, and it is a guide for people in their actions. It is a ploy, or a manoeuvre, used to eliminate the opponent. Also, it determines the course of action as a pattern. In addition, strategy is taking a position, which means taking a place and surviving in the environment where the organization does business. Moreover, it is a perspective which helps to create a vision shared by all the members of the organization.

Strategy is deliberately created by the executives in order to achieve the organizational goals. For this reason, a strategy created for an organization cannot be useful for the others. For this reason, the strategies must be genuine. As the strategies are created for the benefits of an organization, they must be expressed clearly and all the members must be informed about it. The strategies and the plans related to those strategies for the planned future are determined by the managers or the managerial board of those organizations. The whole work in the organizations can be the part of strategic management because managers are aware of the fact that they must direct the organization to the defined goals. During the management process, the managers at different levels use variety of strategies. Using strategies in an organized way in the process of management has brought out the term "strategic management" (Bryson, 2004). 
Strategic management helps to make decisions the complex situations. By the help of new technologies, the managers get lots of information from different fields and levels at an increasing speed. This information flow may disturb daily managerial work at some time. In those times, when the managers have to cope with the challenges of daily managerial work, strategic management is advised to apply.

Strategic management involves not only setting the strategies that are crucial for an organization to control its environment in order to reach its goals but also making and applying the decisions to implement those strategies. Therefore, strategic management describes the managerial process of getting an organization from its position to the desired level. It is not similar to the daily managerial work because it deals with the basic issues of an organization (Hannagan, 2001). Moreover, strategic management includes planning the strategies after research, investigation and evaluation; taking precautions; and the processes taken while achieving the goals. Using the strategic management approach, the managers evaluate the local and global conditions, and determine the opportunities and threats. After determining those threats and opportunities, the managers set the strategic visions (Eren, 2008).

The process of strategic management combines strategic planning, implementation, performance management elements continuously and in a cyclical way. The answers to some questions like "Where are we? Where do we want to be? How do we achieve the goals? How do we measure the development?" show what to accomplish in the phases of strategic management process (Olsen \& Haslett, 2002). One of the most important phases of strategic management is strategic planning which helps the organizations be aware of themselves, understand the meaning of their existence, determine their goals and decide on the strategies to reach those goals.

Strategic planning shows an organization's implementation of a strategy, the organization's goals and the methods to be used in order to achieve those goals (Olsen, 2007). It started in the 1960s by the term "corporate planning". The term emerged because there was a need for a plan which would cover the whole organization. Moreover, strategic planning includes the short and long term plans of the whole organization. Through those plans, the managers generate the strategies which would carry the organization to the planned future. During the period following the corporate planning, it was emphasized by the researchers that strategic planning must be in the centre of management because "strategic planning" is a comprehensive process including short and long term plans needed for the achievement of the goals (Hussey, 1998).

Strategic planning is a way for the organizations to adapt to the changing environment they operate. It guides the organization in determining the basic decisions and actions. It also provides information to the organization about (1) where the organization is (mission, structure, communication, programs, employees skills, budget and supports), (2) where the organization wants to be (resources available, analysis of interior and exterior environment and vision), (3) how to reach that place (the methods) (Bryson, 2004). For this reason, it is thought that the organizations which value the strategic planning would benefit from it in time because planning would help the organizations to adapt and survive in the competitive environment they operate.

To have a successful planning, people in the organization must believe in the strategic planning. As some researchers pointed out, one of the most important obstacles in the strategic planning is that people in the organizations have negative attitudes at the beginning (Baloğlu, Karadağ and Karaman, 2008). Moreover, as seen in the studies on educational organizations, the strategic plans were stored as documents but not put into action (Şahin and Aslan, 2008). 
Strategic planning process is not a duty of only the managerial board but it needs participation of individuals of all stages in the organization. This participation enables the organizations to share different point of views and different opportunities. By helping the organization operate successfully in the dynamic and complex environment, strategic planning transforms the organizations' bureaucratic structure into a flexible form and directs the organization to change (Hunger \& Wheelen, 2011). Active participation is considered an important factor in strategic planning. Therefore, the studies have pointed out that the individuals in the organization must be included in the strategic planning process and their contributions must be taken into consideration (Küçüksüleymanoğlu, 2008). As it is a comprehensive process which could mean the construction of the future of an organization, including the all the individuals in the process of strategic planning helps the plans to be more efficient and increases the individuals' level of acceptance it. As Altınkurt (2010) stated the success of the strategic planning is possible if all the members of an organization own it. Besides, Demirbolat (2005) indicated that embracing the strategic planning has various benefits to the organization; such as turning it into a learning organization, reacting the changes immediately and increasing the productivity.

In order to implement the plans successfully, there is a need for the individuals to have strategic consciousness. If the organizations employ people who have the strategic consciousness, they can react the changes faster, which would be an important factor for the strategic planning to achieve the goals (Çetin, 2013).

In the preparation stage of the strategic planning, the coordination must be arranged by the upper level management. However, the employees at all levels are needed to participate. This participation not only produces a more effective planning but also individuals' level of embracing the plans would be higher since they have contributed to it in the preparation stage. The strategic plans which communicate an organization's mission, vision, and capacities make the employees' jobs more meaningful. As they know their organization better by knowing their organization's goals, capacities and planned investments, the employees strive for the planned future. This situation is mainly related to the strategic planning consciousness level. It can be said that in the organizations where people have adequate information about strategic planning and where they have acquired the importance of strategic planning it can be faster to reach the goals stated in the plans.

\section{The Problem}

As the workforce in the organizations changes in time, the employees' consciousness level on the strategic planning is essential because having a consciousness level of planning, the individuals can contribute to their organization's plans and work in order to reach the organizational goals. The employees who contributed to the plans prepared two or three years ago may not be working in the same organization now. Similarly, the employees who have started working in the organization may not be aware of the organization's strategic plan.

Because it is a plan that includes all the people from the top management to the workers at the lowest level, employees' level of information about the current strategic plans is seen as an important factor in the efficiency level of strategic plans as it has been pointed out in the researches mentioned. Therefore, the employees' consciousness level of strategic planning is seen as a problem to be researched. 


\section{The aim of the study}

This research aimed to search the lecturers' (employed at the Eskişehir Osmangazi University, Department of Foreign Languages) consciousness level and views on strategic planning. The research aimed to answer the following questions:

1. Is the consciousness level of the lecturers have a significant difference according to

a. their working time in the organization

b. their education level

2. What are the views of the lecturers on "the importance of strategic planning", "active role in strategic planning" and "strategic planning consciousness level"?

\section{The significance of the study}

The studies about the strategic planning in the educational organizations in Turkey have been about the teachers' and the school leaders' views on and the attitudes towards the strategic planning. (Küçüksüleymanoğlu, 2004; Altınkurt, 2007; Nartgün, 1996). In those studies, the challenges faced during the preparation and implementation stage of the strategic planning were revealed, and some suggestions were made.

Some other studies focused on the benefits of strategic planning (Işı1k ve Aypay, 2004), and the importance of the planning for the educational institutions. As Çalık (2003) pointed out planning is necessary in order to achieve the desired goals and strategic planning has an important impact on the success. Besides, Çetin (2013) researched the teachers' and school leaders' the consciousness level of strategic planning and the problems faced during the strategic planning process in the public schools of the Ministry of National Education. The results showed that the teachers participated in the research had negative attitude towards strategic planning while the school managers had more positive attitudes. Research also revealed that there were some problems. For example, the responsibility of preparation and implementation of strategic planning is on the similar people; there is no harmony between the shareholders; and also the employees had negative attitude towards strategic planning.

In Turkey, the strategic planning work in the state institutions started after the "Public Financial Management and Control Law (law no: 5018)" was passed in the parliament. The law describes the strategic planning as "it is a plan that consists of the short and long term goals of the public institutions, their basic principles and policies, their aims and priorities, the methods and resources to be used to reach those goals (Resmi Gazete, 2003, December)." According to this law, the state institutions' budgets, investments and annual expenditures would be determined in parallel with their strategic plans. As the educational institutions have a mission of providing the individuals with high quality education, it is necessary for those institutions to employ people who have strategic consciousness.

Apart from the schools of The Ministry of National Education, especially in the university level, there is a need for research on strategic planning consciousness level. For this reason, the results of this study are important, as they would give information about strategic planning consciousness level and views on the strategic planning at university level. In this study, lecturers' (who are at the lowest rank in the academic/university hierarchy) strategic planning consciousness level and views on strategic planning were researched. As Hunger and Wheelen (2011) suggested, participation in strategic planning and high consciousness level of strategic planning are beneficial for an organization. Therefore, knowing the lecturers' consciousness level and their views on the strategic planning would also show the importance given to the planning in the organization, which also has a significance. 


\section{METHOD}

\section{Research Model}

This research, which aimed to find out the lecturers' strategic planning consciousness level and views on strategic planning, was designed in the form of the convergent parallel mixed methods design. This research design aims to collect complementary data on the same subject. This method requires collecting and analysing quantitative and qualitative data similtaneously and combining them in the discussion part (Creswell and Plano Clark, 2014).

In the quantitative part of the research, data were collected by the instrument developed by Çetin (2013). The items in the instrument were modified as they would be answered online and could be saved in one of the researchers' Google ${ }^{\mathcal{O}}$ account. After that the participants were reached by e-mail. The data were analysed by using the SPSS 16 programme and were discussed. In the qualitative part of the study, which is the qualitative part, a semi-structured form that consists of open-ended questions and prepared by the researchers was used. The answers by the participants were collected and a code (LEC) was assigned to each answer. The answers were analysed by Nvivo 11 programme Descriptive analysis techniques were applied in order to analyse the answers. This technique includes summarizing and discussing the results according to the themes constructed before. Direct quotations are used to reflect the views of the participants. The aim in this technique is to present and interpret the results in a theme. To achieve this, the data must be described in a systematic way. After that, those descriptions are explained, interpreted and the results are shown (Yıldırım and Şimşek, 2006, p. 224).

\section{Population}

The population includes the lecturers employed at Eskişehir Osmangazi University, Foreign Languages Department. In order to make the research, the researchers had the permission from the Rectorate of the university. During the research there were 70 lecturers at the department. In the quantitative part, 46 lecturers participated, which makes the $65 \%$ of the population. In the qualitative part of the population, 26 people participated the study. There are 10 people $(21,7 \%)$ who has worked between $1-5$ years; there are 13 people $(28,3 \%)$ who has worked between $6-10$ years; there are 11 people $(23,9 \%)$ who has worked between $11-15$ years; and there are 12 people $(26,1 \%)$ who has worked over 16 years. Educational status of the lecturers is as follows: 11 people $(23,9 \%)$ have the BA degree, $23(50 \%)$ people have the MA degree, and 12 people $(26,1 \%)$ have the education at $\mathrm{PhD}$ degree.

In the qualitative phase of the research, 23 lecturers participated which makes the $50 \%$ of the people who answered the instrument. There are 4 people $(17,3 \%)$ who has worked between $1-5$ years; there are 5 people $(21,7 \%)$ who has worked between $6-10$ years; there are 5 people $(21,7 \%)$ who has worked between $11-15$ years; and there are 9 people $(39,1 \%)$ who has worked over 16 years. Educational status of the lecturers, who participated in the qualitative part is as follows: 4 people $(17,3 \%)$ have the BA degree, $15(65,2 \%)$ people have the MA degree, and 4 people $(17,4 \%)$ have the education at $\mathrm{PhD}$ degree.

\section{Instruments}

In the quantitative part of the study, "Strategic Planning Consciousness Level Attitude Instrument" developed by Çetin (2013) was used. In order to use the instrument, the researchers got permission from the developer via e-mail. In the qualitative part of the research, a form prepared by the researchers was used. This form, called "Views of the Strategic Planning", has open-ended questions and provides information parallel with the instrument used in the 
quantitative part of the study. The participants' answers to the questions were put together according to the themes designed before.

\section{Strategic Planning Consciousness Level Attitude Instrument}

The Strategic Planning Consciousness Level Attitude Instrument consists of 14 items and its content validity, plot study and construct validity studies were done by Çetin (2013). His studies showed that the instrument had four factors, which are 1. The knowledge about strategic planning (item no: 1,2,3,4), 2. Negative attitude about strategic planning (item no: 5,6,7), 3. Strategic planning belief (item no: 8,9,10,11), 4. Active role in strategic planning (item no: 12,13,14). The reliability coefficient of the factors in the instrument are as follows: 1 . The knowledge about strategic planning: ,77; 2. Negative attitude about strategic planning: ,71; 3. Strategic planning belief ,71; 4. Active role in strategic planning ,69 (Çetin, 2013). The instrument was prepared to be applied to the schools in the Ministry of National Education; therefore, the items in the last factor were modified so that they could be meaningful in the university context.

\section{Strategic Planning Views Form}

Strategic Planning views form, which was developed by the researchers, has six openended questions. The form was designed to get information in parallel with the instrument used in the first part of the study because the research design needs qualitative and quantitative information to support each other. The form has two parts. The first part asks questions about the demographic features of the participants, and in the second part there are 6 questions. With these questions the participants' views were asked for on these themes: (1) the importance of the strategic planning (questions 1 and 5), (2) active role in the strategic planning (questions 2and 4), (3) strategic planning consciousness level (questions 3 and 6).

The questions are as follows:

1. What importance has strategic planning got for the future of the organizations?

2. By whom the strategic planning of an organization should be known?

3. If all the employees are aware of the strategic planning, what would an organization benefit from it?

4. How do the employees help the managers in the achievement of the goals in the strategic planning?

5. Do you think the employees must be informed when the goals have been achieved or not?

a. Yes (Why and how frequently must the employees be informed?)

b. No (Why do you think they must not be informed?)

6. What is your level of information about the strategic plan of your own organization?

The first draft of the form was shown to some professors working at the education faculties of Anadolu University and Eskişehir Osmangazi University. Based on the professors' views, the form was completed, and given to the participants.

\section{Data analysis}

Data analysis part was carried out in two phases. In the first part, quantitative data were analysed by using SPSS 16 programme. In the data analysis, the mean values of the answers in the first part of the research were used to determine the lecturers' consciousness level. To see 
if the data has normal distribution or not, Kolmogorov-Smirnov test was applied and it was seen that the data weren't distributed normally. Therefore, to see the if there is a significant difference between groups, non-parametric tests (Kruskal- Wallis H and Mann-Whitney U Test) were applied. In the qualitative part, the data were analysed by Nvivo 11 programme. In this analysis, descriptive analysis techniques were used.

\section{FINDINGS}

\section{A. Lecturers' strategic planning consciousness level}

Table 1 shows the lecturers' strategic planning consciousness level. As it is seen in the table, the lecturers' knowledge level is low (mean: 2,0272) in the first factor, which is the knowledge about strategic planning. In the second factor, which is the negative attitude about strategic planning, the lecturers are seen to have middle level of negative attitude (mean: $2,8188)$. In the next factor, strategic planning belief, the lecturers are seen to have middle level of belief in strategic planning (mean: 2,5815). According to the final factor, which is active role in strategic planning, the lecturers opinions show that the active role should be on the managers (mean: 3,5072).

Table 1. Lecturers' strategic planning consciousness level

\begin{tabular}{|c|c|c|c|c|}
\hline Items & Low & High & Mean & St. Dev. \\
\hline $\begin{array}{l}\text { 1. I have got adequate information about strategic planning. } \\
\text { 2. I have got adequate information about Public Financial }\end{array}$ & 1,00 & 5,00 & 2,0435 & 1,03186 \\
\hline Management and Control Law (law no: 5018). & 1,00 & 3,00 & 1,2826 & ,58359 \\
\hline $\begin{array}{l}\text { 3. I believe that the strategic planning of our organization really } \\
\text { contributes the goals. } \\
\text { 4. Being an educator, I believe in and support strategic planning. }\end{array}$ & $\begin{array}{l}1,00 \\
1,00\end{array}$ & $\begin{array}{l}5,00 \\
5,00\end{array}$ & $\begin{array}{l}2,0435 \\
2,7391\end{array}$ & $\begin{array}{l}1,03186 \\
1,23711\end{array}$ \\
\hline Factor 1. The knowledge about strategic planning & 1,00 & 3,75 & 2,0272 & ,69966 \\
\hline 5. I think strategic planning is paperwork. & 1,00 & 5,00 & 2,1087 & 1,05889 \\
\hline 6. I think strategic plan is just a document. & 1,00 & 5,00 & 2,1087 & 1,26891 \\
\hline $\begin{array}{l}\text { 7. My views weren't taken into account in preparation stage of the } \\
\text { strategic planning. }\end{array}$ & 1,00 & 5,00 & 4,2391 & 1,03676 \\
\hline Factor 2. The negative attitude about strategic planning & 1,00 & 5,00 & 2,8188 &, 80033 \\
\hline $\begin{array}{l}\text { 8. Strategic planning has brought a new perspective to our } \\
\text { organization. }\end{array}$ & 1,00 & 4,00 & 2,1522 & ,91815 \\
\hline 9. I believe we had enough training on strategic planning. & 1,00 & 5,00 & 1,3261 & ,81797 \\
\hline $\begin{array}{l}\text { 10. I believe strategic planning is necessary for the educational } \\
\text { organizations. }\end{array}$ & 2,00 & 5,00 & 4,2609 & ,92939 \\
\hline $\begin{array}{l}\text { 11. I believe the evaluations made at the end of the strategic } \\
\text { planning are realistic. }\end{array}$ & 1,00 & 5,00 & 2,5870 & ,97925 \\
\hline Factor 3. Strategic planning belief & 1,50 & 4,00 & 2,5815 &, 56533 \\
\hline $\begin{array}{l}\text { 12. In the application process of strategic planning, the department } \\
\text { managers have the active role. }\end{array}$ & 1,00 & 5,00 & 3,5217 & ,96007 \\
\hline $\begin{array}{l}\text { 13. In the application process of strategic planning, the faculty } \\
\text { managers have the active role. }\end{array}$ & 1,00 & 5,00 & 3,2391 & 1,03676 \\
\hline $\begin{array}{l}\text { 14. In the application process of strategic planning, the university } \\
\text { management team have the active role. }\end{array}$ & 1,00 & 5,00 & 3,7609 & 1,09919 \\
\hline Factor 4. Active role in strategic planning & 1,00 & 5,00 & 3,5072 & ,89922 \\
\hline
\end{tabular}

The results of the Kolmogorov-Simirnov test (Table 2) show that the data aren't distributed normally except the third factor. Therefore, the Kruskall-Wallis H Test was applied to see if there was a significant difference among the groups in the independent variables of working time and educational status of the lecturers. 
Table 2. Kolmogorov-Smirnov Test showing the normality of the data

\begin{tabular}{lrrr}
\hline Factors & Statistic & N & \multicolumn{1}{c}{ Sig. } \\
\hline F1. The knowledge about strategic planning &, 176 & 46 &, 001 \\
F2. The negative attitude about strategic planning &, 171 & 46 &, 002 \\
F3. Strategic planning belief &, 097 & 46 &, $200^{*}$ \\
F4. Active role in strategic planning &, 178 & 46 &, 001 \\
\hline $\mathrm{P}<.05$ & & &
\end{tabular}

As the data weren't distributed normally, the Kruskall-Wallis H test was applied in order to see is if there is a difference among the participants in the variables of working time and their education levels. The results are given in the table 3 and 4 .

\section{Consciousness level of the lecturers according to their working time in the organization}

Table 3. The results of Kruskall-Walls Test showing the differences among the groups in the independent variable of working time

\begin{tabular}{llll}
\hline \multicolumn{1}{c}{ Factors } & Statistic & N & Sig. \\
\hline F1. The knowledge about strategic planning & Kruskall-Wallis & 46 &, 423 \\
F2. The negative attitude about strategic planning & Kruskall-Wallis & 46 &, 259 \\
F3. Strategic planning belief & Kruskall-Wallis & 46 &, 128 \\
F4. Active role in strategic planning & Kruskall-Wallis & 46 &, 641 \\
\hline P $<.05$ & &
\end{tabular}

$\mathrm{P}<.05$

As table 3 shows, there is no significant difference among the lecturers in the variable of working time in the organization. This result shows that although the lecturers working time in the organization is different, they have similar approaches to strategic planning. The human resources in an organization changes in time, so it is expected that participation in strategic planning or the information about it can change in terms of working time in an organization. However, in this research, it was found out that there is no significant difference among the people who have been working for different periods of time in the organization. This may show the fact that there is not enough importance given to strategic planning in the organization.

\section{Consciousness level of the lecturers according to their education level}

Table 4. The results of Kruskall-Walls Test showing the differences among the groups in the independent variable of educational level

\begin{tabular}{llll}
\hline \multicolumn{1}{c}{ Factors } & Statistic & N & Sig. \\
\hline & & & \\
F1. The knowledge about strategic planning & Kruskall-Wallis & 46 &, 948 \\
F2. The negative attitude about strategic planning & Kruskall-Wallis & 46 &, 951 \\
F3. Strategic planning belief & Kruskall-Wallis & 46 &, 291 \\
F4. Active role in strategic planning & Kruskall-Wallis & 46 &, $034^{*}$ \\
\hline P<.05
\end{tabular}

$\mathrm{P}<.05$

As table 4 shows, there is a significant difference among the lecturers in the variable of educational level. The difference is seen in the factor "active role in strategic planning." Participation in strategic planning and the individuals' active contribution to the strategic planning are important factors in the efficiency of the plans. Therefore, having different approaches on the active role in strategic planning can be expected. To see the differences between the groups Mann-Whitney U Test was applied. The results are shown in Table 5. 
Table 5. The Results of Mann-Whitney U Test showing which groups have the significant difference

\begin{tabular}{lllcll}
\hline Grup 1/Grup 2 & Test Statistic & Std. Error & Std. Test Statistic & Sig. & Adj. Sig. \\
\hline PhD / BA & 7,750 & 5,639 & 1,374 &, 169 &, 508 \\
PhD / MA & 12,104 & 4,657 & 2,599 & 009 &, $028^{*}$ \\
BA / MA & $-4,354$ & 4,957 &,- 878 & 380 & 1,000 \\
\hline P
\end{tabular}

$\mathrm{P}<.05$

Table 5 shows that there is a significant difference among the lecturers who has $\mathrm{PhD}$ and who has MA education. According to the test results, the lecturers who have MA education have higher values $(+12,104)$ than those who have $\mathrm{PhD}$, which means while people with MA education think the active role must be on the managers, those who have $\mathrm{PhD}$ education think the active role must be shared within the organization. Because the plans cover the whole organization and the managers are at the most important position in an organization, it is an expected that the managers must have the active role. As Tokgöz (2012) stated because the decision making process is in the heart of management, it makes the managers the most important human resource in an organization. Therefore, the managers lead the employees to the desired goals by using their leadership skills. In terms of strategic planning, as Besler (2004) mentioned, the main duty of the managers is planning the operations, investments and the growth.

\section{B. Lecturers views on the strategic planning}

The lecturers were given a form to collect supportive information to the quantitative data gathered by the instrument on their consciousness level of strategic planning. In this form, the lecturers were asked some questions about their views on strategic planning. The questions had the same themes to the ones in the first part of the research. The themes are (i) the importance of strategic planning, (ii) active role in strategic planning, (iii) strategic planning the consciousness. The knowledge about strategic planning and strategic planning belief are thought to be about the strategic planning consciousness. Therefore, the factors are combined into one theme in this part. The themes gathered in this part of the study are shown in figure 1.

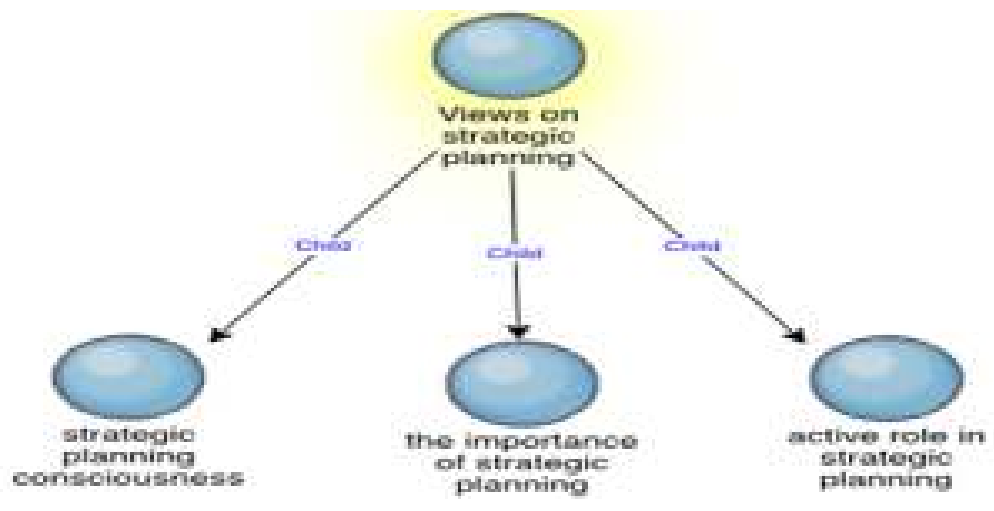

Figure 1. Views on strategic planning.

\section{i. the importance of strategic planning}

According to the answers gathered in the first theme, the importance of strategic planning, all the participants pointed out that strategic planning is "important" for an organization. According to the views, the strategic plan is important and informing the employees would help the organization. Figure 2 shows how strategic planning helps an organization. According to the participants' views, strategic planning "increases motivation, 
develops vision, enhances sense of organizational belonging, increases the level of embracing the plans, provides sustainable success and improvement, creates awareness about the plans"

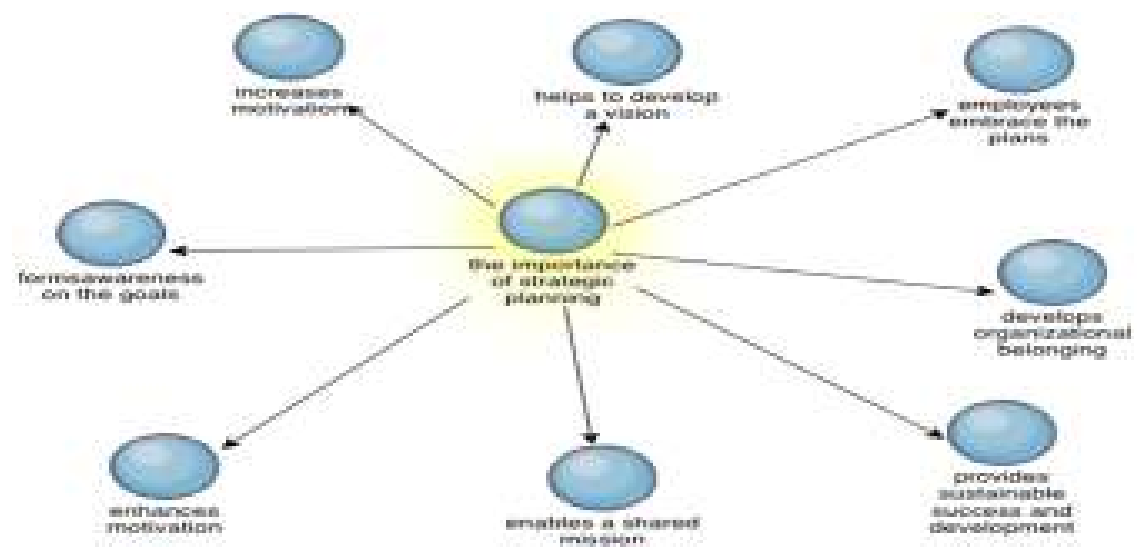

Figure 2. The importance of strategic planning

Some of the answers given to support this view are as follows: Strategic planning is important; LEC 1: "to achieve a sustainable success and development," LEC 2: "to develop the products and the services," LEC 11: "to determine a vision and mission, and therefore establishing the goals and to reach those goals," LEC 12: "the successes are sustainable," LEC 13: "it would increase the educational development. Also, it would increase the motivation of the employees. It would help develop a organizational culture and increase the efficiency of the educational programmes, " LEC 16: "it is necessary to run the organization completely."

Some of the views showing why this informing is necessary are as follows: LEC 2: "the organization's success and failures must be shared with the employees with the reasons and results in good or bad times, " LEC 3: "the employees feel that they belong to the organization," LEC 5: "it affects the employees' motivation and performance," LEC 10: "because the organization and its strategic plan belong to everybody in the organization," LEC 14: "the employees see where they are on the way to the goals."

The participants' opinions on the frequency of the informing vary. They think that informing can be (a) at regular intervals, (b) depends on the organizational culture, (c) once or twice a year, (d) if the managers need it (see Figure 3).

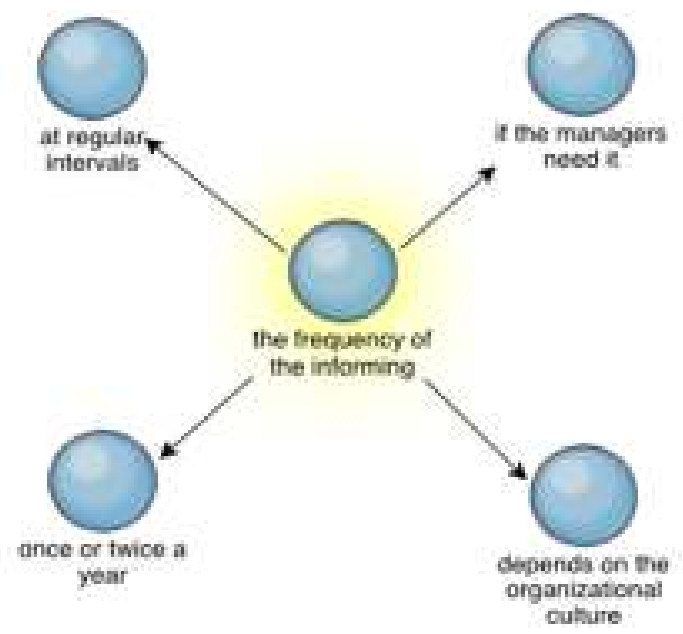

Figure 3. The frequency of informing 
Some of the views of the lecturers are as follows: LEC 16: "the employees must be informed at the beginning, middle and end of the process," LEC 17: "once or twice a year," LEC 19: "they must be informed always," LEC 3: "the details and the frequency must be determined as it is necessary," LEC 15: "the feedback must be as frequent as possible," LEC 23: "I think it is enough to inform once a year."

With the answers in this theme, it can be said that the participants think the strategic planning is important for an organization for some reasons and it provides some help to the managers and the organization in total. Also, the participants pointed out that informing the employees about the strategic planning would be beneficial for the organization and the employees must be informed about the strategic planning process on regular intervals.

\section{ii. active role in strategic planning}

The lecturers' answers to the second theme, active role in strategic planning, showed that nearly all of the participants (22 of the 23 participants) think that the strategic plan of an organization must be known by all the employees in an organization. However, one lecturer (LEC 9) stated that "only the people in charge" must know about it. Some of the views of the other lecturers are as follows: LEC 17: "everybody must know it (strategic plan) and everybody must work for its goals." LEC 11: "the plan must be known by all the employees of the organization." LEC 22: "I think people who want to know must know it." LEC 15: "everybody in the organization must know it." LEC 13: "the details of the strategic plans must be known by some experts in the organization; moreover, each member in the organization must know their responsibilities and duties." LEC 7: "the experts on strategic planning must know the detailed parts of the plans but members must know their duties and responsibilities in order to achieve the goals."

In the answers to the question which asks about the employees' supports to the managers in achieving the goals, the participants expressed that the employees must help the managers. In figure 4, the employees' contributions to the strategic planning can be seen. The findings indicate that the employees can contribute to their organization by "providing feedback, giving different views and sharing information, fulfilling their duties and responsibilities.

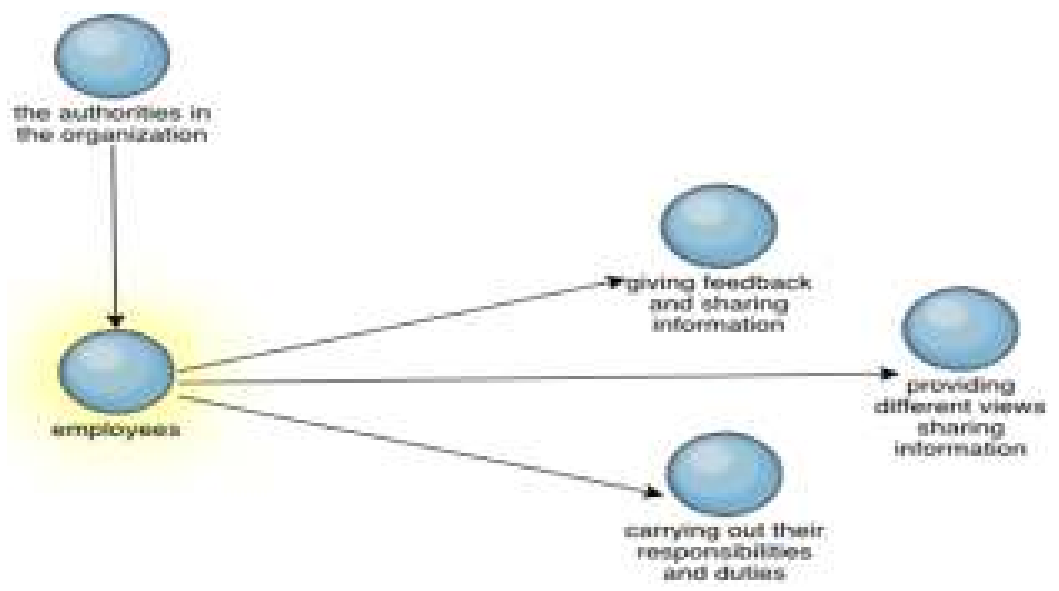

Figure 4. The employees' contributions to the strategic plan

Some of the views in this issue are as follows: LEC 22: "(the employees) can give feedback about the process. " LEC 1: "employees can help the managers by achieving the goals and by working according to their job requirements. " LEC 5: "by playing an active role." LEC 9: "by doing their duties. " LEC 10: "By giving feedback about the work." LEC 12: "by giving feedback about the problems in the process and helping to take precautions on time." LEC 20: "Getting information about the strategic planning in an organization helps the managers to see 
the organization from a wider perspective...the employees have a big role in communicating the bad and good things to the managers.

The answers in the theme active role in strategic planning showed that the participants think that the whole organization must play an active role in the planning process. In addition, everybody has a role in strategic planning process. It is stated that the employees can help the managers by fulfilling their duties.

\section{iii. Strategic planning the consciousness}

The answers to the questions in the third theme, strategic planning consciousness, show that most of the lecturers (92\%) expressed that they don't have adequate information about the strategic plan of their own organization. Two of them (8\%) said they had enough information, however, 11 of them (48\%) expressed they had nearly no information and 10 of them (44\%) said they had no information.

Some of the answers to the questions are as follows: LEC 5: "I have nearly no idea", LEC 10: "I have no information", LEC 17: "Zero. Because no one knows what this organization knows except the managers." LEC 19: "Nearly none". LEC 3: "I have enough information about the plans but not much detailed", LEC 1: "very little", LEC 2: "on the web page of the organization people can reach the plans. Besides, especially during my graduate studies, I had the opportunity to share information on the preparation, implementation processes."

However, all of the lecturers participated in the research stated that being aware of the strategic plan of the organization contributes to the organization in different ways. Those contributions are seen in Figure 4. As the participants pointed out strategic planning consciousness "increases motivation, increases efficiency, improves organizational culture, increases organizational belonging, improvement in team spirit, and the goals can be reached easily"

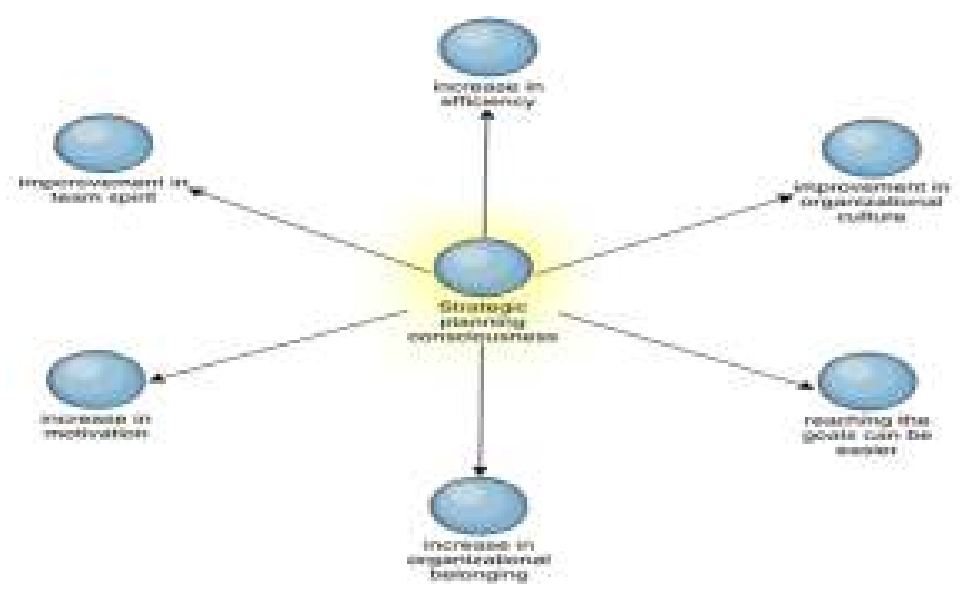

Figure 4. The contributions of strategic planning to the organization.

Some examples of the participants are: LEC 1. "all of the employees become aware of the organizational goals and this helps reaching the goals," LEC 19: "it provides all the employees' contribution, having an active role, having a team spirit." LEC 11: "it helps create an organizational culture," LEC 12: "When people believe that the energy they spend, the job they do and the results are meaningful, they work more enthusiastically, which contributes to the performance directly. LEC 3: "It is important to feel that people belong to that organization. This would enhance the motivation level. LEC 22: "It would increase the motivation of the employees in planning process and in their work." 
The participants' answers in this theme showed that most of them had no adequate information about the plans. However, it is stated by the participants that being aware of strategic planning would contribute the organization in different ways.

Table 6 shows the summary of the participants views on strategic planning, the themes, the views on these themes and the main ideas in the qualitative part of the research.

Table 6. The views of Strategic Planning

\begin{tabular}{|c|c|c|}
\hline Themes & Main Ideas & Explanatory Examples \\
\hline \multirow{3}{*}{$\begin{array}{l}\text { The } \\
\text { importance of } \\
\text { strategic } \\
\text { planning }\end{array}$} & $\begin{array}{l}\text { Strategic planning has an important } \\
\text { role in an organization. }\end{array}$ & $\begin{array}{l}\text { Provides sustainable success and development. } \\
\text { Provides a shared mission. } \\
\text { Improves the vision. } \\
\text { Increases the motivation }\end{array}$ \\
\hline & \multirow[t]{2}{*}{$\begin{array}{l}\text { The employees must be informed when } \\
\text { the goals are achieved. }\end{array}$} & $\begin{array}{l}\text { Establishes awareness about the plans. } \\
\text { Provides feeling of organizational belonging. } \\
\text { Employees interiorise the plans. }\end{array}$ \\
\hline & & $\begin{array}{l}\text { On regular intervals. } \\
\text { Depends on the organizational culture. } \\
\text { Once or twice a year. } \\
\text { If the managers need. }\end{array}$ \\
\hline \multirow{2}{*}{$\begin{array}{l}\text { Active role in } \\
\text { strategic } \\
\text { planning }\end{array}$} & $\begin{array}{l}\text { Strategic plans must be known by all } \\
\text { the members of the organization. }\end{array}$ & $\begin{array}{l}\text { Everybody must know and be directed to the goals. } \\
\text { All the employees must know. } \\
\text { The experts about the strategic planning must know } \\
\text { well and everybody must contribute. }\end{array}$ \\
\hline & $\begin{array}{l}\text { The employees must help the managers } \\
\text { to reach the goals by }\end{array}$ & $\begin{array}{l}\text { Fulfilling their duties and responsibilities to achieve the } \\
\text { goals. } \\
\text { Providing feedback. } \\
\text { Providing different views and sharing information. }\end{array}$ \\
\hline \multirow[b]{2}{*}{$\begin{array}{l}\text { Strategic } \\
\text { planning } \\
\text { consciousness }\end{array}$} & $\begin{array}{l}\text { I have no idea about the strategic plan } \\
\text { of my organization }(92 \%) \text {. }\end{array}$ & $\begin{array}{l}\text { I have information ( } 2 \text { people, } 8 \%) \\
\text { I have (nearly) no idea ( } 11 \text { people, } 48 \% \text { ). } \\
\text { I have no idea ( } 10 \text { people, } 44 \%)\end{array}$ \\
\hline & $\begin{array}{l}\text { Strategic planning is beneficial for an } \\
\text { organization. }\end{array}$ & $\begin{array}{l}\text { Reaching the goals becomes easier. } \\
\text { Increases efficiency. } \\
\text { Increases organizational belonging. } \\
\text { Increases motivation. } \\
\text { Develops teams spirit. } \\
\text { Improves organizational culture. }\end{array}$ \\
\hline
\end{tabular}

\section{DISCUSSION}

In this study, it was found that the lecturers' consciousness level of strategic planning is low and there is no significant difference among the lecturers in terms of working time in the organization and educational status. However, there was a significant difference in the factor called "active role in strategic planning" between the employees who have MA education and $\mathrm{PhD}$ education. While the lecturers who have $\mathrm{PhD}$ education think that the active role must be shared among the people in the organization rather than the managers, those who have MA education tend to think that the managers must have the active role. The results of some previous studies on strategic planning showed that the strategic planning consciousness level of the employees is lower than of managers. On this sense, the findings in this research has some parallel results with Çetin's (2013) research. In his study, he found out that the managers had higher consciousness level than the employees. This result shows that if people participated in the strategic planning activities and were aware of the planning, their level of consciousness would be higher.

When the participants' strategic planning consciousness level and their views on strategic planning are analysed, it was found out that there are both positive and negative views. 
The participants stated that they have "little information" about strategic planning in the factor called knowledge about strategic planning, and they have "middle level negative attitude" on the factor called negative attitude on strategic planning. In the studies it was found out that if the individuals believe in the importance of the strategic planning, they show positive attitudes; however, if they have negative attitudes they think that the plans are just a procedure to be completed and sent to the managers at the upper level. Similarly, in Şahin and Aslan's (2008) research the results revealed negative attitudes. The results showed that some school principals completed the strategic planning process as it was wanted by the upper level managers. Also they pointed out that the plans were never put into action.

In the other part of the research, which was about the active role in strategic planning, the participants expressed that the active role must be on the managers except for those who have $\mathrm{PhD}$ education. The studies on strategic planning showed that the managers had more active role. As Besler (2004) stated the managers have the roles to coordinate the operations forward, arrange the investments and provide growth, which are among the main elements of strategic planning. Therefore, it can be suggested that the managers must be active in communicating the strategic planning process.

The second part of the research was about the participants' views on strategic planning. The answers given to the questions in the first theme showed that the all participants believe that the strategic planning is quite important for an organization. However, although they emphasized that it has a crucial importance, it is not explained why they have low strategic planning consciousness and have no information about their organization's strategic plan. The findings on the benefits of strategic planning are similar to the ones in Altınkurt's (2010) research, in which the participants pointed out that strategic planning contributes development, efficiency and productivity. Likewise, Demirbolat (2005) stated that strategic planning would change the organization's thinking style, turn an organization into a learning organization. He also expressed that by making the individuals' responsibilities clearer the productivity would increase. Moreover, Gürer (2006) stated that one of the benefits of strategic planning is creating a learning organization by increasing the organizational learning. The other benefit can be using the resources efficiently. The success of the planning would be achieved by the embracing the plans both by the decision makers and the employees in the whole organization.

In the answers to the other question in the same theme, the participants stated that the employees have to be informed about the strategic planning process. As Yelken, Kilıç and Üredi (2010) pointed out during the preparation stage of planning the practitioners must be included in the process as the cooperation and communication is important in strategic planning. In order to get the success, the shareholders must be included in the implementation process. In our study, the views showed that regular information flow has the potential of increasing strategic planning consciousness level. Although the participants' consciousness level is low, they think that regular information flow is necessary. The low consciousness level may be because there is not a regular information flow in their own organization, or there are some communication problems because as it was expressed in the findings they had no information about their own organization's strategic plan.

The second theme is the active role in strategic planning. In this theme the answers to the factor in the first part of the research showed that they believe that the managers would have the active role as it is pointed out in the literature. In the second part, although nearly all of the participants expressed that all the employees must be aware of the plans, it was found out that they don't have enough information about their own organization's plans. It is thought that this may be due to inadequate information about the strategic planning. However, the participants expressed that the employees provide some contributions to the managers, which show that 
they are enthusiastic about it. The views can be concluded that the strategic planning is teamwork. Therefore, although managers should have the active role, the employees are in the key position to achieve the goals. Because the shareholders are the ones who play an important role in developing strategies and policies, without getting participation of the shareholders in the strategic planning process, it would be difficult to fulfil the needs and there would be problems in the process of implementing the plans and reaching the main goals. As Arıbaş (2013) states participation is important in getting different views. As a result, in every phase of strategic planning shareholder contribution is a must.

The views on the last theme, strategic planning consciousness, showed that the participants had no information about their own organization's strategic plan. Yet, the participants expressed that having information about the strategic plan is beneficial for the organization. Some of those benefits are the increase in organizational belonging and motivation, having a positive organizational culture. Thinking that planning is beneficial but having no information about it can be explained by the lack of organizational information flow. Therefore the managers must pay attention to inform all the employees about the plans. As Özmutaf (2007) expressed a participative approach in strategic planning helps the performance in the organization. Besides, when the managers provide a democratic and participative atmosphere during the planning process, the employees would interiorise the goals easily.

\section{RESULTS and RECOMMENDATIONS}

The results of this research, which aimed to find out the lecturers' consciousness level and views on strategic planning, showed that the participants' strategic planning consciousness level is low. There is no significant difference among the participants in terms of their working time in the organization. However, in the factor, active role in the strategic planning, there is a difference between the employees with MA education and $\mathrm{PhD}$ education. The participants who took part in this research stated that strategic planning has a crucial importance for an organization's future and it enhances productivity, increases motivation and organizational belonging.

Besides, the participants have middle level negative attitude towards strategic planning. In the qualitative part of the research, the participants' views which give importance on the benefits of strategic planning show that they believe in strategic planning. However, having low consciousness level could be caused by the organizational attitude, not their own.

Next, the participants emphasised that the employees must be informed regularly when the goals are met because this information would increase the motivation and organizational belonging. Since the most important goal of the strategic planning is to take an organization to the desired level, achieving those goals mean that the plan has been successful. Therefore, informing the employees when the goals are met is thought as a duty for the managers. Also, the participants' strategic planning belief was low. Some participants, as seen in different studies, think that strategic planning is unnecessary. But informing the employees about the achievement of the goals may destroy this attitude.

Furthermore, the participants expressed that the managers must have the active role in strategic planning but the employees' contribution is vital because the organization consists of the individuals who want to achieve the desired goals. In this structure, the managers have the responsibility to coordinate the planning and involve all the employees. Besides, the employees have to work for the desired goals and take part in the planning process.

It was also found out that most of the participants don't have enough information about the plans of their own organization. Although they indicated that strategic planning is essential, 
having no information about their own organization's plans may be because of the lack of information or having low level of strategic planning belief.

As the lecturers' consciousness level is low at the organization where the research was carried out, there are some important things to do for the strategic planning to be successful. For example, the employees must be informed about the goals and results in the strategic plan when the goals are achieved. Furthermore, in order to increase the strategic planning consciousness level, there must be participation of the whole organization. Finally, the managers must motivate the employees about the strategic planning and must express their expectations from them.

\section{Bibliography}

Altınkurt, Y. (2007). Strategic leadership in educational organizations and strategic leadership applications of school principals (Unpublished doctoral dissertation). Anadolu University, Eskişehir, Turkey.

Altınkurt, Y. (2010). Attitudes of Employees of Provincial Directorates of National Education and School Administrators towards Strategic Planning. Educational Sciences: Theory \& Practice, 10 (4), 1947-1968.

Arıbaş, N. N. (2013). Dimensions of "Participation” In Public Strategic Planning. Journal of Academic Approaches, 4 (1), pp. 80-100.

Baloğlu, N., Karadağ, E., Karaman, H. (2008). The strategic planning attitude scale: a study of exploratory and confirmatory factor analyses. Educational Sciences: Theory \& Practice, 8 (2), pp. 407-437.

Besler, S. (2004). Işsletmelerde stratejik liderlik [Strategic management in organizations]. İstanbul: Beta

Bryson, J. M. (2004). Strategic planning for public and nonprofit organizations. San Francisco: Jossey-Bass.

Çalık, T. (2003). Eğitimde stratejik planlama ve okulların stratejik planlama açısından nitel değerlendirilmesi [Strategic planning in education and the qualitative evaluation of the schools as regards to strategical planning]. Kastamonu Eğitim Dergisi, 11(2), pp. 251-268.

Çetin, H. (2013). Eğitim kurumlarında stratejik planlama bilinç düzeyi ve stratejik yönetimde karşılaşılan sorunlar: Denizli İli örneği [The level of consciouness in strategic planning in educational institutions and the problems experienced in strategic management: A sample of Denizli]. Mustafa Kemal Üniversitesi Sosyal Bilimler Enstitüsü Dergisi, 10 (24), pp, 87-112.

Creswell, J.W. \& Plano Clark, V.L. (2014). Desinging and conducting mixed methods research [Karma yöntem araştırmaları: tasarımı ve yürütülmesi]. Yüksel Dede \& Selçuk Beşir Demir (Eds). Ankara: Anı

Demirbolat, A. O. (2005). Strategic planning in educational management and leadership roles in determining the vision and the mission. Education and Science, 30 (135), pp, 58-65.

Ebner, D. (2012). Formal and Informal Strategic Planning. Innsbruck, Austria: Springer Gabler.

Eren, E. (2008). Stratejik Yönetim [Strategic management]. Eskişehir: Anadolu University Publications.

Floyd, P. (2002). Organizational change. Oxford: Capstone.

Gürer, H. (2006). Stratejik planlamanın temelleri ve Türk kamu yönetiminde uygulanmasına yönelik öneriler [Fundamentals of strategic planning and proposals for implementation in Turkish public administration]. Sayıştay Dergisi, 63, pp, 91-105. 
Hannagan, T. (2001). Mastering strategic management. Palgrave-Macmillan.

Hunger, J. D., \& Wheelen, T. L. (2011). Essentials for strategic management. (5 ${ }^{\text {th }}$ ed.). New Jersey: Prentice Hall.

Hussey, D. (1998). Srategic management: from theory to implementation (4 ${ }^{\text {th }}$ ed.). Oxford: Butterworth-Heinemann.

Işık, H. \& Aypay, A. (2004). Eğitimde stratejik planlama sürecinde karşılaşılan sorunlar: Çanakkale ilinde yapilan bir inceleme. [Problems faced in the process of strategic planning in education: A study conducted in Çanakkale] Gazi Üniversitesi Gazi Ĕ̈itim Fakültesi Dergisi, 24 (3), pp, 349-363.

Küçüksüleymanoğlu, R. (2004). İlköğretim okullarında stratejik planlama çalışması (Bursa İli Canaydın Illkögretim okulu örneği) [Strategic planning in primary schools (Bursa Province Canaydin Elementary school case)] (Unpublished doctoral dissertation). Anadolu University, Eskişehir, Turkey.

Küçüksüleymanoğlu, R. (2008). Stratejik planlama süreci [Strategic planning process]. Kastamonu Ĕ̈itim Dergisi, 16 (2), pp, 403-412.

Mintzberg, H. (1996). Five ps for strategy. In H. Mintzberg, \& J. B. Quinn (Eds). The strategy process: concepts, contexts, cases (pp. 10-18). London: Prentice Hall.

Nartgün, Ş. S. (1996). Yüksekögretimde stratejik planlamanın uygulanabilirliği [Applicability of strategic planning in higher education] (Unpublished master's thesis). Abant Izzet Baysal University, Bolu, Turkey.

Olsen, E. (2007). Strategic planning for dummies. Indianapolis: Willey.

Olsen, J. E., \& Haslett, T. (2002). Strategic management in action. Systemic Practice and Action Research, 15(6), pp, 449-464.

Özmutaf, N. M. (2007). Örgütlerde bireysel performans unsurları ve çatışma [Individual performance components and conflict in organizations]. C. Ü. İktisadi ve İdari Bilimler Dergisi, 8 (2), pp, 4160

Resmi Gazete (2003). Kamu mali yönetimi ve kontrol kanunu (5018) [Public financial management and control Law (5018)], 24/12/2003 No:25326.

Şahin, S.ve Aslan, N. (2008). İlköğretim okul yöneticilerinin stratejik planlamaya ilişkin görüşleri üzerine nitel bir çalışma (Gaziantep ili örneği) [A qualitative study on primary school principals' views on strategic planning (case of Gaziantep city)]. Gaziantep Üniversitesi Sosyal Bilimler Dergisi, 7(1), pp, 172-189.

Tokgöz, N. (2012). Stratejik yönetim I [Strategic Management I] (Ed. Deniz Taşçı \& İ. Cemil Ulukan). Eskişehir: Anadolu University Publications.

Yelken, T. Y., K1lıç, F., \& Üredi, L. (2010). Stratejik planlama uygulamalarını ilişkin ilk ve orta öğretim okul müdürlerinin görüşleri [Primary and secondary school teachers' Views on strategic planning aplications]. International Journal of Eurasia Social Sciences, 1 (1), pp, 38-50.

Yıldırım, A. \& Şimşek, H. (2006). Sosyal bilimlerde nitel araştırma yöntemleri [Qualitative research methods in social sciences] ( $6^{\text {th }}$ ed). Seçkin: Ankara. 